\title{
Operational activity of the central bank
}

\author{
Volodymyr Lanovyi \\ Ph.D., Head of Securities Transactions Division, National Bank of Ukraine, Ukraine
}

\begin{abstract}
The paper presents the results of the investigation of central bank's operations from theoretical and practical point of view. Theoretical aspects of the open market operations were analyzed. The definition of the open market operations was formulated. The principles was formed, the typology and the classification of the open market operations was developed. The features, main advantages and disadvantages of such transactions was defined. The issues of the interdependence of the three levels of monetary policy's aims and its relationship with operational tools of the central bank were considered.
\end{abstract}

Keywords: monetary policy instruments, central bank, open market operations, standing facilities, refinancing operations, certificates of deposit.

JEL Classification: E43, E52, E58, G10.

DOI: $10.21272 /$ fmir.1(2).60-70.2017.

(C) The Author, 2017. This article is published with open access at ARMG Publishing.

\section{Introduction}

Monetary operations refer to the implementation of monetary policy - ensuring that a central bank's policy decision has the intended impact on financial markets, and on the economy more generally. For operational purposes the day-to-day tactical target is usually to achieve a particular level of interest rates or the exchange rate; and the most efficient instruments are those which best complement the workings of a market system. Central banks have an interest in well-functioning money markets, foreign exchange markets, and secondary markets for government securities. Efficient financial markets support both the monetary stability and financial stability goals of the central bank; and more broadly should benefit economic development. Wellfunctioning money markets support the transmission of an interest-rate based monetary policy and can provide information to the central bank. Liquid foreign exchange markets can help to stabilise the exchange rate and reduce transaction costs in cross-border trade and transfers. The development of these markets will support the later introduction of related financial markets such as repo and derivatives, which should in turn lead to improved risk management and financial stability, thereby enhancing economic welfare. Liquidity and price stability in short-term interest rate markets can support market-making, and thus liquidity in the securities markets. This in turn should reduce the cost of issuance for the government and other fixed-interest issuers. Indeed the secondary market for government securities may act as a catalyst for wider fixed income securities markets development: its yield curve is the benchmark for the pricing of the private sector credit. The advancement of these markets should be accompanied by the development of the appropriate market infrastructure such as robust payment and settlement systems and supportive legal framework.

The operational activity of the central bank on the open market differs by individual influence on bank liquidity, in contrast to some other monetary mechanisms, in particular, the normalization of mandatory bank reserves, which affect all banks equally. In addition, an open market operation is not a compulsory tool. Therefore only those banks wishing to carry out such operations take part in them. That is, these operations affect the liquidity of individual financial institutions and change the structure of the resources of the credit and banking system.

Principles, the typology and the classification of the open market operations of central bank remain not fully formulated. We set the goal to define the features, main advantages and disadvantages of such transactions and to consider issues of the interdependence of the three levels of monetary policy's aims and its relationship with operational tools of the central bank.

\section{Literature review}

The activity of central banks in the open market was investigated by foreign scientists, employees of central banks and international organizations. So S. Fullwiler [5] describe ten general principles of modern central bank operations. These ten principles are not intended to be exhaustive or comprehensive; neither are the 
discussions of the individual principles necessarily exhaustive. Rather, these principles represent "what every economist should now be expected to know" given the large quantities of orthodox and heterodox research in this area and the empirical or anecdotal evidence contained in speeches and publications of central bank officials. As noted already, this research generally confirms the earlier points made by Moore [14] and other authors associated in one way or another with the horizontalist literature.

S. Gray, N. Talbot [6] examined the various different instruments: open market operations; standing facilities; and both required reserves (which have some of the characteristics of direct controls), and voluntary or contractual reserves. Open market operations are undertaken at the initiative of the central bank, whereas standing facilities are used at the initiative of the commercial banks. Participation in both is voluntary at the level of individual banks, whereas in most countries reserve requirements are an administrative imposition on all banks - albeit one which, through averaging, allows them a degree of day-to-day flexibility. Monetary instruments are not only used to implement monetary policy; they are also used for liquidity management. This is an essential part of the central bank's operations, in order to prevent the short-term uncertainty and price volatility which day-to-day swings in market liquidity would otherwise cause. Gray, N. Talbot [6] therefore also considered liquidity forecasting and management issues.

Many developing economies are characterised by illiquidity in these core markets, and in most cases a surplus of central bank money, in the form of excess commercial bank balances with the central bank. Gray, N. Talbot looked at what the central bank, and the Ministry of Finance as issuer of government securities, could do (and in some cases should not do) in support of the development of these markets.

The book of Bindseil U. [15] is entirely dedicated to the implementation of monetary policy: how central banks go about achieving their monetary policy targets. Monetary policy implementation has gone through tremendous changes over the last twenty years, which have witnessed the quiet end of 'reserve position doctrine' and the return of an explicit focus on short-term interest rates. This book argues that reserve position doctrine has never, and could never, be seriously put into practice. Providing a simple theory of monetary policy implementation, Bindseil goes on to explain the role of the three main instruments (open market operations, standing facilities, and reserve requirements) and reviews their use in the twentieth century.

At the same time, summarizing the results of scientific research in this direction, we can state that further studies require theoretical and applied questions to clarify the nature and classification of OMO (open market operations); establishing the relationship between the main objectives and the tools for achieving them; substantiation of the importance of activities in the open market when the central bank performs monetary and credit regulation; development of instruments of the central bank's activity on the open market and increase of its efficiency.

\section{The main findings of the study}

Among Ukrainian scientists, the most complete analysis of the category of "open market operations" is given, in our opinion, by V. Mishchenko and A. Somyk [1]. These operations include credit and deposit repo transactions, sales and purchase transactions of assets (securities or currency). These authors give the following classification of open market operations:

$>$ regular open market operations.

$>$ operations for refinancing or depositing for a long period (from 3 to 12 months).

$>$ adjustment operations.

$>$ structural operations.

We believe that such a classification is sufficiently comprehensive and does not contradict the generally accepted international practice and simultaneously fully corresponds to the classification that the European Central Bank cites [2, p. 10-11]. Indeed, open market operations should be divided by their nature, reasons and objectives.

In contrast to the above position, the American researcher F. Mishkin [3, p. 483] divides open market operations into two types: dynamic and protective operations. Dynamic operations of the open market, in his opinion, aimed at changing the volume of reserves and monetary base, and protective ones - to lessen the impact on the monetary base of other factors (for example, in the US - by changing the Treasury's funds on the accounts of the Federal Reserve System or cash volumes). 
Despite some differences of opinion on the composition of the central bank's operations on the open market, a definitive general definition can be formulated. Open market operations (OMO) are direct and reverse operations with securities and other financial instruments that the central bank implements on market principles in a clear relationship with the objective function of monetary policy in order to ensure the equilibrium of the money market, optimize the volume and structure of the liquidity of the banking system, as well as management of short-term interest rates of the interbank credit market.

Open market operations should be initiated by the central bank after an assessment of the situation in the monetary market and the decision to intervene in market processes. In the implementation of such operations, the central bank uses only market mechanisms and rates, act indirectly, non-administratively, and act as an ordinary counterparty for a commercial bank. Unlike open market operations, central bank operations for permanent mechanisms (deposit or credit) are initiated by commercial lending institutions after the conditions for such operations are announced by the central bank. Thus, it can be said that it is the regulator who is interested in and initiates open market operations.

The main objective of open market operations is to increase or reduce the amount of money that is controlled by financial institutions. Such operations, in the first place, affect the bank reserves, as well as because of the multiplier effect, on the supply of loans and economic activity in general.

F. Mishkin [3, p. 485-486] highlighted the following advantages of open market operations in comparison with other instruments of monetary policy:

$>$ open market operations are carried out on the initiative of the central bank, which can control their volume;

$>$ open market operations are flexible and accurate enough, they can be implemented in various volumes, depending on the situation in the money markets and the objectives of monetary policy;

$>$ open market operations, if necessary, can be canceled, that is, have the opposite effect;

$>$ open market operations are performed fairly quickly, they do not depend on administrative delays.

An important contribution to the study of the operational activities of central banks was also made by the Russian researcher Sergei Moiseev. Investigating the technical procedures used by them in the conduct of operations with securities on the open market, he proposed a certain classification of them [4, p. 331-332]:

$>$ under the terms of the agreements (direct transaction or purchase and sale transaction for a period with the obligation of repurchase under pre-agreed conditions);

$>$ on the subject of transactions (transactions with government, corporate or other securities);

$>$ on terms (overnight, short-term and others);

$>$ on the composition of counterparties (mainly - banks, as well as non-banking institutions or the financial sector as a whole);

$>$ by the method of setting the interest rate (market or fixed by the regulator)

$>$ by the method of determining the volume of the transaction (market or regulator)

$>$ on the initiator of the agreement (market or regulator).

However, we consider it necessary to note that, by definition of open market operations, they are initiated precisely by the monetary regulator, and not by the market (the activity of commercial financial institutions), but on the terms that have developed in the market. Therefore, the selection in the above classification of such features as the way to determine the scope of an operation, the way to establish interest rates, and the initiator of an agreement, is not entirely appropriate. However, the author did not point to some significant signs of the open market operating activity of central banks, which, in our opinion, make the classification more precise and complete. We suggest expanding the classification criteria by adding the following criteria:

$>$ in the direction of the transaction (for absorbing or supplying liquidity);

$>$ on asset security (secured or not provided);

$>$ for currency, the volume of which is regulated (national or foreign);

$>$ on procedures that are used (on a tender or bilaterally basis);

$>$ for the subject of regulation (liquidity of the banking system, a separate commercial bank or interbank interest rates).

According to the above additions, we consider it expedient to consider the composition of operations on new grounds, for example, in the direction of action and the procedures for conducting operations. 
The instruments for performing open market operations are systematized in Figure 1 (see in Appendix) depending on the direction of the operation-the supply or absorption of liquidity.

Thus, the open market operations for the supply of liquidity include direct purchases of securities, direct repo operations, refinancing on security of assets and currency swap operations (national versus foreign exchange). In our opinion, it is expedient to classify the open market operations for liquidity absorption as direct sales of securities, reverse repo transactions, currency swap operations (foreign versus the national currency), issuance of central bank debt and placement of deposits of commercial banks in a central bank on an auction basis.

Next, we consider the instruments for implementing open market operations, depending on one more proposed feature - the procedure for conducting - on a bilateral or tender (auction) basis.

On a bilateral basis, direct sales of securities on the open market are conducted. With the help of tenders, the following operations are conducted: refinancing operations by the central bank on the security of assets, placement of the debtor's obligations (bonds or certificates of deposit) in the primary market, auctions for placement of commercial banks' deposits with the central bank. The operations of direct / reverse repo and currency swap can be carried out both on a tender and on a bilateral basis, depending on the object of liquidity regulation by the central bank (the banking system as a whole or a separate commercial bank).

Such an approach can be applied to the distribution of the instruments of operations in the open market, depending on the provision of assets. Thus, secured loans are banks refinancing on bail and repo transactions, all the rest are unsecured.

According to the next sign - the currency, the volume of which is regulated, - open market operations are carried out both in national and foreign currency, determined by the monetary regulator.

The last of the classification criteria proposed by us - on the subject of regulation - delineates the instruments of operations into the following groups: to regulate the liquidity of the entire banking system (repo tenders, currency swaps, refinancing loans, stock exchange transactions of securities, issue of own debt obligations, and placement of deposits in the central bank on a tender basis), to regulate the liquidity of a separate commercial financial institution - the purchase and sale of securities on the OTC market, repo and currency swap transactions, implemented on a bilateral basis.

It is pertinent to note that individual instruments perform a similar role and are aimed at similar regulatory outcomes. Thus, the issue of own debt obligations and deposits in the central bank, from the point of view of influence on changes in the money supply, are identical. Their main difference is that in the first case, securities or certificates of deposit issued by a central bank may have circulation on the secondary market, and, therefore, is a more liquid instrument for commercial banks. Any bank that owns this financial asset can easily sell it on the exchange or over-the-counter markets, depending on the existing stock infrastructure. For the central bank, this may mean that the servicing of liquidity absorption operations will be carried out at a lower cost to it, since the interest rate of attraction directly depends on the liquidity of the instrument. For market participants, the use of tools that can be accessed on the secondary market makes it possible to significantly increase their provision with secondary liquidity resources.

Direct repo transactions and the refinancing mechanism of commercial banks on the security of assets by character and direction of action are also similar to credit instruments. Their differences lie in the fact that repo transactions can be carried out both on a tender and on a bilateral basis, when the central bank works directly with the counterparty, and not with the market as a whole, and loans secured by assets of this property do not have. By bilateral transactions, the central bank regulates the liquidity of an individual commercial bank of direction. Another advantage of the repo instrument is that legally the ownership of the assets that are used as collateral for the operation passes to the mortgagee (central bank), but the mortgagor remains in possession of them economically. That is, the assets of the central bank are accounted for in the off-balance account, and all economic benefits (interest income, etc.) remain with the mortgagor. This allows to significantly reduce the risks of the regulator associated with the default of the counterparty, which is especially important in the context of insufficiently effective judicial and legal systems of the country.

We can note that, in our opinion, among the similar operations of the monetary regulator (issue of own debt obligations and placement of deposits in the central bank, direct repo and refinancing of banks on the security of assets), the issuer's own debt securities and direct repo operations are more effective. When using such instruments, the central bank uses market interest rates to prevent excessive amounts of their use. Despite this, 
a significant number of central banks go by the parallel application of all instruments, because each of them has its own peculiarities of application, can have undeniable advantages in a particular situation in the monetary system.

Taking into account the above conclusions and generalizations, we will form the final, in our opinion, list of signs of classification of open market operations (Figure 2, see in Appendix).

The process of further improving the operating activity of the regulator in the open market, which occurs in the economically developed countries of the world, gives grounds for the conclusion that the search for ways to more strictly control the issuing and debt activity of central banks while optimizing the composition of operational instruments is intensified.

In general, it is believed that central banks with large liabilities are exposed to major problems in monetary regulation and may have a conflict of intent with the authorities responsible for managing public debt. If at the same time there is a structural excess of liquidity in the system, its absorption by means of the regulator becomes impossible. A typical situation when there is a lack of overall internal liquidity, but instead of overcoming such countries should get rid of structural excess liquidity.

For example, in Brazil, there is a ban on the issuance by the central bank of debt securities [10] and the transfer of the cost of sterilization operations of excess liquidity and currency transactions to the fiscal body. As a consequence, the central bank uses the repo instrument to conduct its monetary operations. Every 6 months, the accounts between the central bank and the state treasury are "cleared" to prevent the accumulation of significant net claims. In addition, the Brazilian treasury is required to provide the central bank with the appropriate volume of treasury securities for the implementation of monetary policy, in particular for sterilization of excess liquidity, which occurs when currency is bought into the central bank's foreign exchange reserves.

In Mexico, the debts of the central bank were replaced by domestic public debt, while the reduction of the state's external debt and the currency reserves of the central bank led to a reduction in the cost of sterilization operations.

In India, in February 2003, the government prepaid external debt with an average maturity of 9.3 years in the amount of USD 3 billions. The foreign currency for such an operation was received by the government from the Reserve Bank of India (Reserve Bank of India, further - RBI) in exchange for an equivalent number of marketable domestic debt securities through private placement. With the help of such operations, RBI received assets, later used to sterilize excess liquidity, while reducing its vulnerability to currency risk.

In India, as in some other countries, the central bank is prohibited from issuing debt instruments. Significant and sustained capital injections led to the fact that RBI felt a shortage of monetary instruments for sterilization purposes. Therefore, there were created, as a government instrument, stabilization bonds (Market Stabilization Bonds, further - MSB), which absorbed long-term excess liquidity outside that which could be sterilized through the traditional daily repo operations of RBI. The proceeds from operations were placed on the unprofitable account of the Stabilization Fund (the Market Stabilization Fund) in RBI. The maturity period, the volume and frequency of MSB auctions are determined by the Indian central bank after agreeing with the state treasury and depend, in particular, on the expected duration and amount of capital investments [11].

The Israeli government issues short-term discount government debt securities (Makam) of the local national central bank to carry out the latter operations with monetary management [12]. After the sale by the Bank of Israel of the above mentioned securities, the money received by it remains on deposit with the central bank and can only be used to repay Makam. The Bank of Israel pays for the deposit an amount that is exactly equal to the yield on Makam. In 2002, the threshold value of the Makam placement volume was canceled, which allowed the Bank of Israel to fully switch to this instrument when performing sterilization operations. In addition, the volume and frequency of issuance of Makam is determined solely by the Bank of Israel, the value of monetary operations is fully paid by the central bank from its revenues, which makes such a tool very flexible in implementing monetary policy. As a consequence, the fullness of the short-term sovereign debt market in local currency has improved, and the fragmentation between the state debt and the central bank's debt has disappeared along with the cancellation of the Makam placement limit value.

Thus, the state treasuries of the countries of the world above, sterilizing the excess liquidity accumulated in the monetary system through the issuance of instruments of domestic public debt, do not allow the central bank to issue its own debt securities and carry out the depositing of remote resources on the accounts of the 
latter on various terms (in India 0\%, Israel and Singapore - at a market interest rate, in Korea - on a separate account with the central bank). Monetary regulators at the same time receive cash for further refinancing operations and structural adjustment of the monetary system, implementing them on the open market.

Such approaches substantially discipline the monetary and debt activities of the central bank, contribute to the stabilization of the national financial system, combining the actions of the government and the regulator in this direction.

As a result of the analysis of the essence and approaches to the classification of central bank operations on the open market, we note the following.

We agree with the position of Ukrainian and foreign researchers, pointing to contractual counterparty nature of such operations of the central bank on the basis and prevailing in financial markets. Such operations can not be regulatory, administrative (on the part of the monetary regulator in relation to commercial financial institutions) content. However, until now it has not been clarified theoretically the determination of the optimal share of such transactions in general monetary and regulatory mechanisms.

The purpose of the relevant operational activities of central banks is to regulate monetary resources and interest rates through four types of operations: regular (permanent, daily) increase or decrease in long-term financial resources; adjusting for unpredictable fluctuations in monetary liquidity and changes in interest rates; formation of long-term proportions (structures) of the financial sector of the economy. However, it remains an open question about the optimal correlation of such types of operations.

Unlike other regulatory mechanisms used by national monetary and emission centers, open market operations are initiated by the latter. Such operations are sufficiently precise and flexible, can have individual meaning and reverse effect, be implemented quickly, without administrative delays. Therefore, their use allows the regulator to better control the situation and gives the right to establish his responsibility for observing certain criteria.

In different countries a wide range of OMO is used, differing by a significant range of features. National regulators also involve a significant range of tools for relevant operational activities. The latter are characterized by the effectiveness of the application (for example, the direction of their stimulating action, the costs incurred by the regulator, the degree of liquidity of the obligation).

These circumstances make it necessary to search for the optimal quality of the operational and regulatory tools and to determine the conditions and limitations for the use of individual instruments, which will eliminate possible failures and errors in the actions of the central bank.

Let's try to combine the system of goals of the central banks, most often used in practice, with the specifics of conducting operations on the open market. Figure 3 shows the specifications of open market operations for each of the operational purposes.

In our opinion, for more effective regulation of the monetary (monetary) base of the central bank, it is more expedient to use:

a) instruments of irreversible impact (direct transactions of currency purchase and sale),

b) reverse instruments (repo transactions and credit operations against assets pledged),

c) market deposit instruments (issuance of securities by the central bank and attraction of deposits of credit institutions) using the procedures of the interest rate tender.

For effective regulation of short-term interbank interest rates, the reverse operations and market deposit instruments of the central bank are applied using quantitative or percentage tender procedures.

Subject to the choice of the operational purpose of the exchange rate of the national currency to foreign as instruments, it is more appropriate to use instruments of currency regulation. This can be currency swap transactions, repo for providing liquidity in foreign currency or for assets denominated in foreign currency and banking metals, any mechanisms for direct participation of the central bank in the interbank foreign exchange market.

It should be noted that in the process of monetary management, in particular when achieving operational goals, central banks use, in addition to specific tools that are inherently targeting a separate variable, as well as other tools that may not in the most effective way affect the operating target. This statement may be relevant in an 
unusual situation. For example, the central bank in the implementation of monetary policy mainly relies on the monitoring of short-term interest rates or monetary base, but because of a breach of the balance of payments or in the case of an unexpectedly rapid outflow of foreign investment from the country, there is a violation of the transmission mechanism of monetary policy. Under these conditions, it is more expedient for a bank to expand its operational instruments with non-specific (to achieve its operational goal) mechanisms aimed at regulating the exchange rate and currency liquidity of the banking system.

All this gives grounds to assert that, from a practical point of view, the key tasks of the central bank's activity on the open market is the proper development and achievement of indicators of operational goals of its activities. Let's consider possible approaches to the solution of this problem.

Due to the fact that most central banks choose the main goal of achieving price stability and economic growth, a certain lag between the activity of the central bank and influence on the main goal often arises. Therefore, central banks use a certain operational goal, an economic variable, to which they can directly influence. In recent years, they prefer to use short-term interbank interest rates as an operational objective [13].

Some central banks of countries with small open economies, where changes in the exchange rate have a direct significant impact on domestic inflation, or in which the level of confidence in the central bank is low, consider the use of the exchange rate as an operational objective more justified.

Choosing the tools of monetary policy, central banks in recent years are more inclined to use indirect market funds. Therefore, they prefer combinations of the latter, namely: open market operations, reserve requirements and permanent mechanisms [14]. Administrative methods of regulation, like setting limits on retail interest rates, have disappeared, as they have become incompatible with market relations and can cause undesirable market distortions.

Obviously, the choice by the central bank of an operational objective does not necessarily determine the boundaries in which it then defines a set of monetary policy instruments. For example, to achieve the target exchange rate, monetary policy instruments can be used to settle market interest rates in accordance with those operating in a country that uses the national currency. And even if the central bank does not offer the exchange rate and interest rates, it can use the same tools to manage daily fluctuations in the liquidity of the banking system in order to prevent volatility and price uncertainty.

The definition of intermediate and operational objectives should be based on certain criteria. Thus, F. Mishkin [3, p. 506-508] cites the following criteria for selecting intermediate goals:

$>$ measurability, that is, the speed and accuracy of measuring intermediate target parameters, can be useful only if it allows us to understand if a policy was chosen before the final (main) goal was achieved;

$>$ controllability, the regulator should effectively manage the indicator chosen as an intermediate goal, and not only monitor it, unable to remedy the situation;

$>$ the most important characteristic of a variable, used as an intermediate goal, should be the predictability of its impact on the final (main) goal. (This characteristic is disputed by many economists, since there is no empirical evidence that some intermediate goals are more closely related to the main goal than others).

Regarding the criteria for choosing operational targets, F. Mishkin notes that they can be based on the same conditions that were used in evaluating intermediate goals. At the same time, it indicates that for the operating variable, the intermediate goal must be finite. That is, it is preferable to choose that operational goal, whose influence on the intermediate is more predictable. In our opinion, the criterion "the predictability of the effect of the intermediate goal on the main and the operating one on the intermediate one" becomes the most significant, provided that other criteria do not allow selecting the most effective target variables. That is, the targets to be chosen are equally measurable and manageable. This happens, for example, when a monetary authority can equally accurately and quickly determine the level of interest rates on interbank loans and the amount of monetary aggregates, provided that both objectives can be equally easily regulated by the available instruments.

Developing the idea of F. Mishkin, the British researcher V. Bindseil [15] writes that the implementation of monetary policy consists of three elements:

$>$ selection of the operational goal;

$>$ defining boundaries to improve control over it;

$>$ using monetary policy tools to achieve the operational goal. 


\section{Conclusions}

Based on the international experience of targeting the activities of central banks, we made the following conclusions.

First, central banks of the world's countries expand the range of intermediate targets of their activities and direct them to several economically important results. This, in our opinion, indicates the expansion of the role of monetary policy in economic development at the present stage.

Secondly, in highly developed countries there is a departure from the setting of intermediate monetary policy goals or there is a refusal to declare such goals as become the subject of the internal "kitchen" of the monetary regulator. We are inclined to the second thought, recognizing the fundamental importance of such intermediate goals as the regulation of the money supply and monetary aggregates to achieve the main goals: financial and price stability, economic growth, employment and others. The same can be said about the role of intermediate benchmarks in countries that prefer directionality to the stability of the exchange rate of the national currency and other similar indicators: regulators are intermediate targets (current account balance of the balance of payments, growth rates of central bank gold and foreign exchange reserves, etc.), but they leave them in the development of monetary policy decisions as a matter of domestic consumption. It is also important that the intermediate reference points have a cross-use, that is, the methods for achieving the necessary monetary aggregates and currency positions are used by the national regulators in parallel in the case of both inflationary and currency-exchange targeting.

Thirdly, the expansion of the list and formulations of the main objectives of monetary regulation that occur in countries with developed market economies and saturated capital markets require adequate operational guidelines for the activities of central banks. Today, the issues of developing a system of operational guidelines for monetary regulation that are adequate and sufficient to achieve a relatively wide range of the main objectives of the central bank's activity are substantially updated.

It should be emphasized that in order to achieve the main, intermediate and operational goals of monetary regulation, it is necessary to build an effective working mechanism of operational and regulatory actions, help to make effective decisions by the central bank and the use of appropriate monetary instruments, in particular, open market operations.

\section{References}

1. Mishchenko, V.I., Somyk, A.V. (2008). Likvidnist' bankivs'koyi systemy Ukrayiny [Liquidity of the banking system of Ukraine]. Naukovo-analitychni materialy, Kyiv: NBU, Tsentr naukovykh doslidzhen', 12, $180 \mathrm{p}$.

2. The implementation of monetary policy in the euro area [Electronic source] / European Central Bank. February 2011. Available at http://www.ecb.int/pub/pdf/other/gendoc2011en.pdf.

3. Mishkin, F. (1999). Ékonomycheskaya teoryya deneh, bankovskoho dela y fynansovykh rynkov: Uchebnoe posobye dlya vuzov [The Economic Theory of Money, Banking and Financial Markets: A Textbook for High Schools]. Moscow: Aspect Press, 820 p.

4. Moiseev, S.R. (2005). Denezhno-kredytnaya polytyka: teoryya y praktyka: ucheb. posobye [Monetary Policy: Theory and Practice: Study]. Moscow: Economist, 652 p.

5. Fullwiler, S. (2008). Modern Central Bank Operations - The General Principles. New York: The Levy Economics Institute, $47 \mathrm{p}$.

6. Gray, S., Talbot, N. (2006). Monetary operations. Bank of England: CCBS Handbook, № 24, 82 p.

7. Monetary policy frameworks and central bank market operations. Bank for International Settlements, Monetary Committee. December 13, 2007. Available at http://www.bis.org/press/p071217.htm.

8. Monetary policy implementation: Monetary policy instruments. European Central Bank. Available at http://www.ecb.europa.eu/mopo/intro/operational/html/index.en.html.

9. The implementation of monetary policy in the euro area. European Central Bank. February 2011. Available at http://www.ecb.int/pub/pdf/other/gendoc2011en.pdf.

10. The Brazilian Fiscal Responsibility Law. World Bank. Available at http://www1.worldbank.org/publicsector/pe/BudgetLaws/BRLRFEnglish.pdf.

11. Launching of Market Stabilisation Scheme. Reserve Bank of India. Available at http://www.rbi.org.in/scripts/BS_PressReleaseDisplay.aspx?prid=9788. 
12. Tools for Implementing Monetary Policy. Bank of Israel. Available at http://www.boi.org.il/en/Markets/DomesticMarketMonetaryTools/Pages/Default.aspx.

13. Gray, S., Talbot, N. (2006). Developing financial markets. Bank of England: CCBS Handbook, \#26, 58 p.

14. Moore, Basil (1988). Horiztonalists and Verticalists: The Macroeconomics of Credit Money. Cambridge, UK: Cambridge University Press.

15. Bindseil, U. (2004). Monetary policy implementation - theory, past and present. New York: Oxford University Press, 288 p.

\section{Appendix}

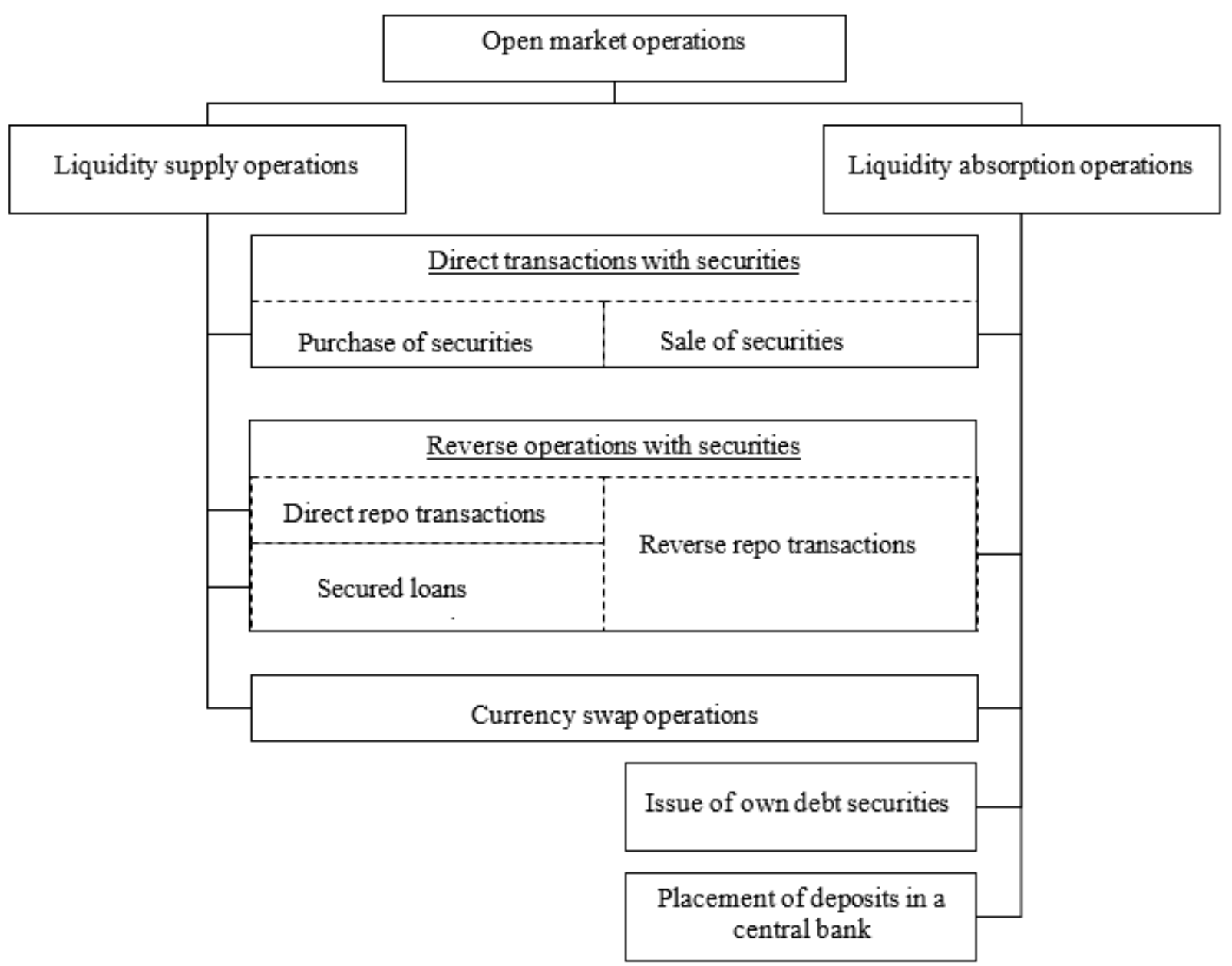

Figure 1. Classification and composition of open market operations depending on the direction of the operation Source: developed by the author. 


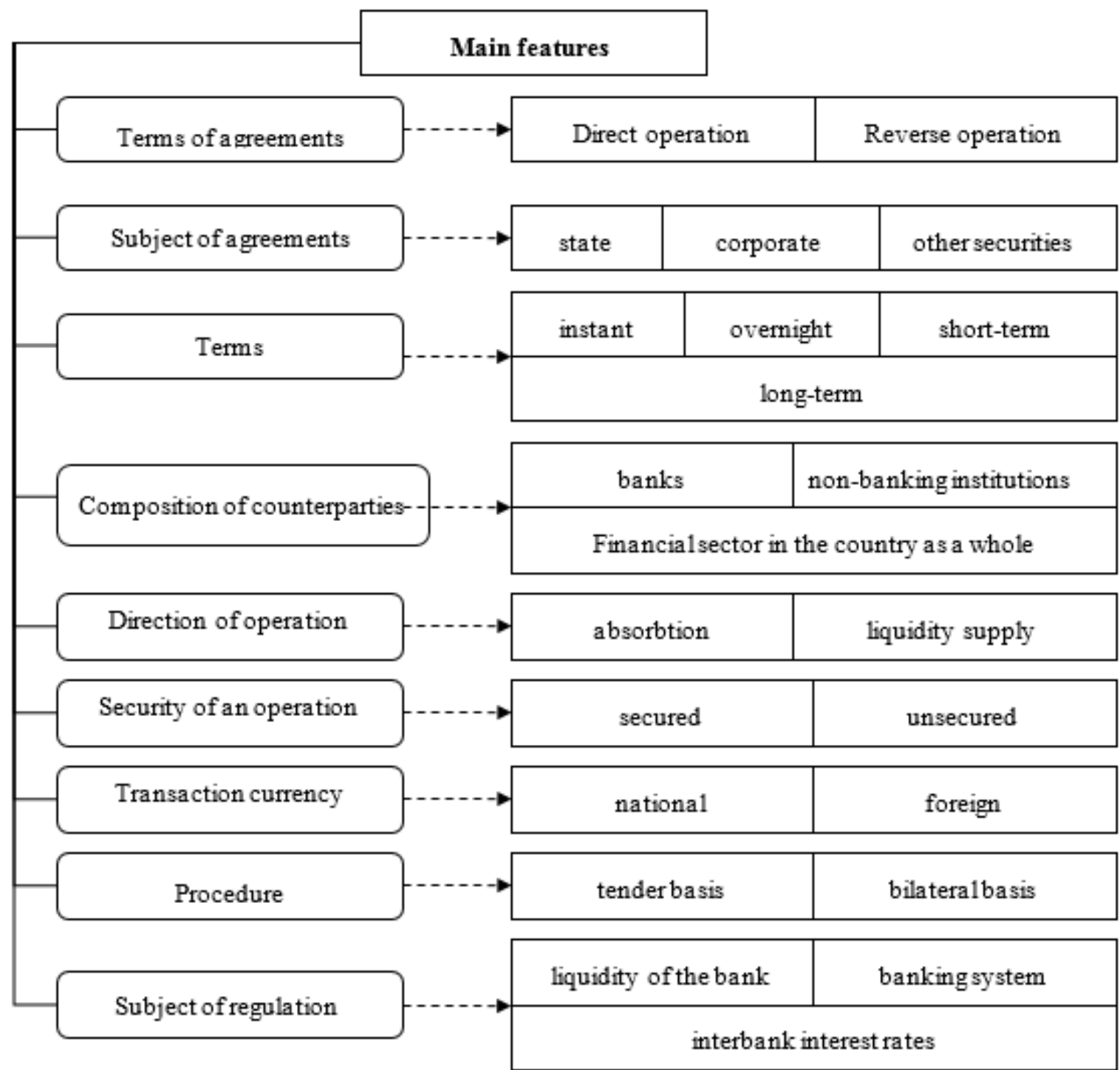

Figure 2. Key features of the classification of open market operations

Source: compiled by the author subject to $[4,5,6,7,8,9]$. 


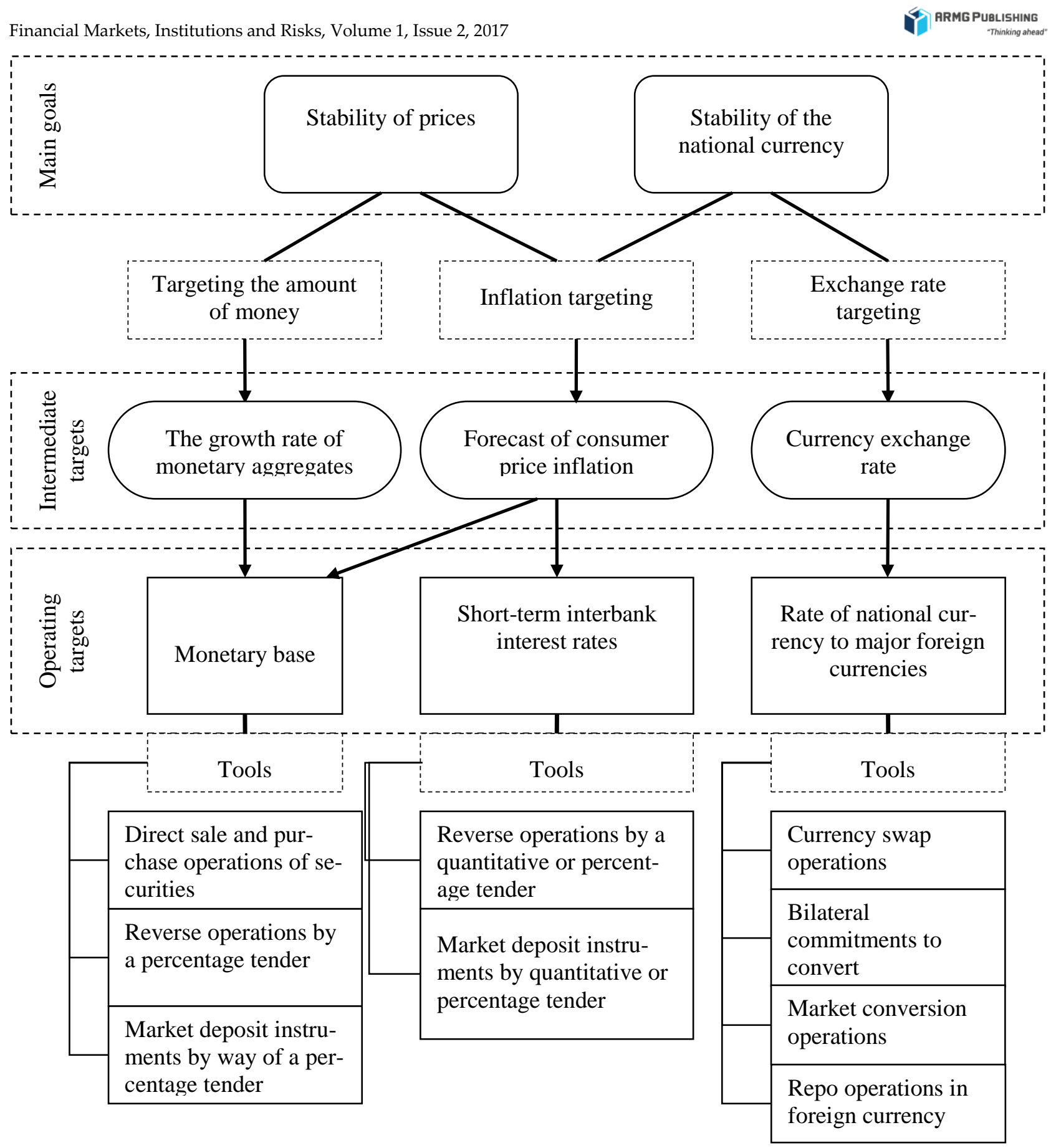

Figure 3. The hierarchy of typical monetary policy objectives and specific operational instruments

Source: developed by the author. 